\title{
The influence of selected demographic variables on the triple bottom line reporting of businesses in the Nelson Mandela Bay
}

\author{
Tony Matchaba-Hove \\ Xolile Antoni \\ Elroy Smith \\ Nelson Mandela University, South Africa
}

\section{Keywords}

Triple bottom line reporting, Sustainability reporting

\begin{abstract}
Triple bottom line reporting is an important aspect of a business's sustainability efforts. The compilation of these reports allows the stakeholders of a business to assess the impact that it has on the economy, society, and environment. This increased stakeholder scrutiny of triple bottom line reports has led businesses that report on the triple bottom line to gain a competitive advantage through increased levels of trust and loyalty from their stakeholders. Other benefits of triple bottom line reporting include employee satisfaction and the minimisation of risk through ethical conduct. The purpose of this article was to investigate the influence of selected demographic variables on the triple bottom line reporting of businesses in the Nelson Mandela Bay region. A quantitative approach was implemented, and a self-administered questionnaire was distributed to the respondents. An exploratory factor analysis was conducted, and Cronbach's alpha coefficients were calculated to assess the validity and reliability of the measuring instrument. The empirical results showed that some demographic variables - the size of the business, the industry in which the business operates, and the management style of the business - had a significant influence on the business's triple bottom line reporting.
\end{abstract}

Corresponding author: Tony Matchaba-Hove

Email addresses for corresponding author: Tony.Matchaba-hove@mandela.ac.za

First submission received: $28^{\text {th }}$ February 2018

Revised submission received: $14^{\text {th }}$ May 2018

Accepted: 25 $5^{\text {th }}$ May 2018

\section{Introduction}

Businesses have traditionally been viewed as entities that are only concerned with maximising shareholders' wealth (Jamali 2006:810). In other words, businesses have viewed the profit-seeking motive as a goal that comes before all other goals (Rogers 2001:280). Thus, businesses' primary goals were to maximise their profit and to translate it into shareholder wealth (Correia, Flynn, Uliana, Wormald \& Dillion 2015:23). However, this narrow approach of maximising business profit and shareholder wealth has left no scope for any other goals to be realised by businesses. Furthermore, the international community has realised that businesses need to take into account the impact they have on a social and environmental level (Dutta 2012:652). This requires a societal focus on environmental longevity and broader issues facing the business and its impact on the world (Sustainability Reporting Program, 2000). This change has required businesses to lessen the chances of their activities causing harm to global resources, and also to evaluate their performance not in terms of profit (economic performance) alone, but according to three factors: economic, environmental, and social (Slabber \& Hall 2011:4). This shift of focus towards sustainability reporting has not been an easy one for businesses to accept.

This is worsened by the fact that there is still no benchmark for companies to evaluate their state of reporting. Businesses are looking for an efficient and relatively standardised reporting mechanism that incorporates transparency and accountability for their economic, environmental, and social impact. Triple bottom line serves as the new multidimensional tool used by businesses to measure their performance. However, triple bottom line reporting is still a new tool, and businesses still lack knowledge of triple bottom line reporting as a concept. The phrase 'triple bottom line' was first to use to refer to the phenomenon of accounting for the social, economic, and environmental impact of businesses (Hindle 
2009). The concept of triple bottom line reporting has attracted a lot of attention and is seen as the fashionable topic in current business discussions (Dutta, 2012:652; Norman \& MacDonald 2004:243). Triple bottom line, which consists of three major pillars - 'people, planet and profit' - expands the regular framework of reporting financial performance to include environmental and social performance (Goel 2010:31).

The long-term survival and success of a business not only means the business should be profitable, but also that it should be ethical and inclusive. Savitz (2006) claims that the triple bottom line interconnects the interests of businesses and communities in a way that measures profit in terms of the financial, environmental, and social performance of the business. The success of triple bottom line reporting has been influenced by factors such as corporate social responsibility, climate change, and fair trade; and it ties in with the goal of the sustainability of business (Hindle 2009).

Therefore, corporate sustainability is a business approach that creates long-term shareholder value by embracing opportunities and managing risks deriving from economic, environmental, and social developments (Wilson 2003:1). Corporate sustainability encompasses three dimensions of needs, known as the 'triple bottom line'. This consists of economic prosperity and opportunity, social equity and quality of life, and ecological resource preservation. Corporate sustainability is an organisational commitment to achieving competitive advantage through the strategic adoption and development of ecologically and socially supportive production processes, products and services, and innovative human resource management practices (Nemli 2004:6).

\section{Literature review}

\subsection{Triple bottom line reporting}

Triple bottom line reporting, as prescribed by The King III code of ethics, allows the industry to set reporting benchmarks that can be targeted by individual businesses (The Business Leaders 2009). The triple bottom line encompasses a complete set of values, issues, and processes that businesses need to address to minimise harmful activities and to create economic, social, and environmental value (Bosch, Tait \& Venter 2006:800). Slaper and Hall (2011:4) add to the definition the notion that triple bottom line follows an accounting framework that incorporates three performance dimensions: social, environment, and financial. These three performance dimensions are also known as 'the three Ps': people, planet, and profits. Yilmaz and Flouris (2010:162) elaborate that the triple bottom line is subdivided into three pillars: the economic, social, and environmental aspects of the business that clearly define targets for sustainable business growth. Goel (2010:31) adds that the triple bottom line is essential for measuring and reporting a business' performance not only for the economy, but also for its social and environmental parameters.

Thus, triple bottom line reporting focuses on the economic, social, and environmental aspects of reporting. It also seeks to enhance the transparency of a business' activities to its stakeholders and involves a holistic view of the effects of business activities on a macro level (Jackson, Boswell \& Davis 2011:56). Goel (2010:27) states that triple bottom line reporting can be identified as an instrument that defines the indicators of social, economic, and environmental activities as prescribed by the Global Reporting Initiative (GRI). This type of reporting also has the ability to show that businesses are concerned and sensitive not only about economic factors, but also about social and environmental factors (Sridhar 2011:50).

\subsection{Environmental sustainability}

The New Zealand Ministry of Education (2012) argues that environmental sustainability is crucial to achieving a sustainable future, and to maintaining the quality of life support systems. Sridhar (2011:51) also explains that environmental sustainability is about preserving the planet's natural resources to ensure that both present and future generations enjoy these resources. Gimenez, Sierra and Rodon (2012:150) state that environmental sustainability consists of two sustainable elements: internal and external environmental programmes. The internal programmes deal with waste management and environmental management systems, while external environmental programmes deal with the positive impact that assessments of and collaborations over supply chain have on economic performances. Gimenez et al. (2012:150) state that environmental issues include waste management, decreasing the use of materials that are toxic or harmful, emissions reduction, pollution reduction, and decreasing the frequency of 
environmental accidents. According to Hellriegel et al. (2012:127), environmental sustainability refers to the dedication of a business to the long-term upkeep of the quality of the environment.

Since environmental sustainability is important, businesses are required to report on their involvement in environmental sustainability. This includes implementation of sound environmental sustainability and using production processes that have minimum harmful effects on the environment (Dutta et al. 2011:2). According to Sridhar (2011:51) environmental sustainability is also important for conserving of all-natural resources for future generations. According to Goel (2010:31), the report should include factors such as the amount of energy consumption and its origins, resources and the material used, and waste management of the business. All this information should be included in the triple bottom line report.

\subsection{Social sustainability}

Social sustainability is about a business committing to improving the standards and quality of life of its community and society (Hellriegel et al. 2012:127; New Zealand Ministry of Education 2012). The New Zealand Ministry of Education (2012) states that social sustainability involves the fair distribution of natural resources as well as the inclusion of people's overall well-being in the strategic plans of businesses. Blowfield and Murray (2008:13) describe social responsibility as the activities in which a business engages to promote economic development, work with employees and their families, and improve the lives of the community in which it operates. Both Orlitzky (2000:5-6) and Simerly (2003:1) have focused on social performance as a configuration of principles of social responsibility, processes of social responsiveness, and policies and programmes as they relate to societal relationships.

The social responsibility of a business is measured by looking into its social performance. Naudé (2008:91) adds that social reporting involves a business that is operating in an environment that is supportive and is a part of its community. Reddy (2007:5) concurs that measuring and reporting on social performance is a key way for triple bottom line businesses to define the social value they create, while holding themselves accountable for the goals articulated in their mission.

Social reporting highlights the relationships a business has with its community (Goel 2010:31). Sridhar (2011:52) and Goel (2010:31) state that these relationships include the health and safety of the community, employee relations, supply chain partners, indigenous rights, and the involvement of the community in the business. Ho and Taylor (2007:127) add that the social report consists of three categories: environmental reports, ethical reports, and reports on employee issues.

\subsection{Economic sustainability}

When a business commits to attending to current business needs and economic viability so as to prepare tactically for its long-term success, that business is considered to have an economically sustainable decision-making process (Hellriegel et al. 2012:127). The New Zealand Ministry of Education (2012) agrees that economic sustainability means the efficient and sustainable use of natural resources to provide goods and services, such that any future generations are not hampered in their production processes. A business must be able to recognise that its own sustainability rests on its ability to work harmoniously in its social and environmental settings. For this reason, the costs of pollution, employee displacement, and other factors should be included in profit calculations. Slaper and Hall (2011:4) argue that economic variables ought to be included as factors influencing the bottom-line and the revenue flow of a business. It should focus on income and expenditure, taxes, business climate factors, employment, and business diversity factors. Specific examples include: personal income; cost of under-employment; job growth; employment distribution by sector; and revenue by sector contributing to gross domestic product (Slaper \& Hall 2011:4). Furthermore, the adoption of triple bottom line is influenced by many factors.

\subsection{Factors influencing the adoption of sustainability practices}

A study investigated the sustainability practices of New Zealand businesses and found an average increase of 10 per cent in the number of businesses that adopted environmental practices between 2003 and 2006. It also found that New Zealand businesses prefer to adopt social practices of sustainability rather than environmental practices. Furthermore, it was found that cost, management time, knowledge, and skills were the greatest barriers to businesses adopting sustainability practices. The study also highlighted that values and beliefs, reputation, and brand were the key drivers in the adoption of 
sustainability practices (Collins, Roper \& Lawrence 2010:492). Another study investigated the current level of emphasis on environmental sustainability among manufacturers in Caribbean countries such as Trinidad and Tobago, Barbados, Jamaica, Guyana, and St Lucia, and found that the major reasons for not investing in sustainability manufacturing were costs, lack of opportunity to practise sustainability, no legal obligations, and lack of awareness or knowledge of sustainability practices.

In terms of the drivers towards sustainability practices, most businesses indicate that they are willing to implement practices if they can see a positive impact on their key performance areas such quality and efficiently reduced waste (Millar \& Russell 2011:521-523). To explain further the factors influencing the adoption of sustainable practices, a study investigated the individual characteristics of business students to predict their attitude towards sustainable business practices. It was found that positive attitudes towards sustainable business practices are predicted by social values, a collectivist orientation, and a transformational leadership style (Ng \& Burke 2010:610). A study by Gomes, Kneipp, Kruglianskas, Rosa \& Bivhueti (2015:117) investigated the relationship between management practices for sustainability and business performance according to the size of business. They found that larger businesses show a high level of adoption of management practices for sustainability (Gomes et al. 2015:125).

Fifka and Meyer (2013:1) conducted an intensive literature review of 186 studies that have examined the determinants of corporate social reporting. They noted that most of the studies (85 per cent) found a positive correlation between size of business, type of industry, country-specific factors, and corporate social responsibility. They found that size and type of industry significantly impact reporting across all regions. This is the case especially for studies conducted in South East Asia in respect of size, and in Southern Europe and Middle East in respect of type of industry (Fifka \& Meyer 2013:1). Furthermore, managerial attitudes were investigated in one region and were found to correlate with corporate social reporting. It was also found that the general political and socio-economic environment has a strong correlation with reporting practices across all the regions that were studied (Fifka \& Meyer 2013:26). Ho and Taylor (2007:145) found that the triple bottom line reporting of 50 large United States and Japanese businesses was higher for larger businesses (size).

A study by Stubbs, Higgins and Milne (2013:456) investigated why 23 of Australia's top 200 companies do not undertake sustainability reporting. It found that none of the companies had experienced stakeholder pressure to report on sustainability issues. Some of the businesses saw such reporting to be a waste of time, distracting them from their core business and not having any effect on their business outcomes. Sustainability reporting was also seen as luxury and not an obligation, and as something that can be implemented at the discretion of the business' management. Additionally, small companies usually felt that they do not have the resources to devote to socially responsible reporting (Stubbs et al. 2013:456).

\section{Problem statement and purpose of the study}

Social and environmental sustainability are merely secondary goals of business, and following the guidelines of triple bottom line reporting can be difficult to maintain as it includes the overall welfare of the community and the environment in which the business is located (Dutta 2012:657; Jackson, Boswell \& Davis 2011:57). Despite the number of studies of triple bottom line reporting, there is a lack of knowledge of triple bottom line reporting by businesses in developing nations (Chapman \& Milne 2003:10-11; Milne, Tregidga \& Walton 2003:15). The discussion above also suggests that a number of businesses seem to undermine the concept of triple bottom line reporting and sustainability. This study thus seeks to investigate whether the demographic variables of businesses in the Nelson Mandela Metropolitan area are associated with the perceived benefits of using triple bottom line reporting.

\section{Research hypotheses}

In order to investigate the influence of selected demographic variables on the triple bottom line reporting of businesses in the Nelson Mandela Metropolitan area, the following hypotheses were formulated and will be subjected to empirical testing in this study: 
$\mathrm{H}^{1 \mathrm{a}-\mathrm{d}}$ : Relationships exist between the selected demographic variables (Size of the business, Industry of the business, Sector of the business, Form of ownership, Management style, and Length of involvement) investigated in this study, and triple bottom line reporting as measured by Benefits of triple bottom line $\left(\mathrm{H}^{1 a}\right)$, Benefits of financial reporting $\left(\mathrm{H}^{1 b}\right),\left(\mathrm{H}^{1 c}\right)$ Benefits of social reporting, and Benefits of environmental reporting $\left(\mathrm{H}^{1 \mathrm{~d}}\right)$.

\section{Research methodology}

This study followed the positivistic research paradigm and adopted a quantitative research methodology and collected primary data from a large sample. This was done to test the hypotheses and to reach the conclusions drawn through logical reasoning.

\subsection{Development of the measuring instrument}

A questionnaire was used as the measuring instrument in the study, and was developed in accordance with the requirements of the study. Keller and Warrack (2003:141) explain self-administered questionnaires as an inexpensive method of conducting surveys, and for that reason they are attractive when a large number of individuals are to be surveyed. The questionnaire was made available to respondents by email and personal delivery. The self-administered questionnaire had three sections:

Section A used a five-point Likert scale to establish the general perceptions of sustainability reporting of businesses in the Nelson Mandela Bay area. The section had ten randomised statements (items). It mainly focused on what triple bottom line reporting leads to with respect to a business' plans and goals. An ordinal scale was used for this section. The five-point Likert scale was understood as $1=$ strongly disagree and $5=$ strongly agree.

Section B also used a five-point Likert scale to establish the perceptions of aspects of triple bottom line reporting of businesses. It had three subsections relating to the aspects of triple bottom line reporting covered by businesses: economic/financial reporting, social responsibility reporting, and environmental reporting. The researchers used an ordinal scale in this section as well. This section had thirty (30) questions - ten from each of the three aspects of triple bottom line reporting.

Section $C$ sought biographical information about the respondents and information about the business. Here a nominal scale was used to collect and analyse the data. It had thirteen questions. The information sought included the gender and ethnicity of the respondents, the size and type of business, how long the business has been involved in triple bottom line reporting, and the aspects that each business covered in its triple bottom line reporting. This information would be used to identify how the demographics of businesses in the Nelson Mandela Bay area influenced their involvement in triple bottom line reporting.

\subsection{Sampling and data collection}

The respondents in the Nelson Mandela Metropolitan area were selected using non-probability sampling methods. For the purposes of the study, both convenience and snowball sampling were employed. Convenience sampling entails the description, identification, and selection of samples to obtain the necessary information. Convenience sampling is a statistical method used for drawing representative data by selecting a sample of people on the basis of their willingness to volunteer, their availability, or easy access (Babbie 2010:192). Snowball sampling is very useful when the population is hidden and difficult to identify (David \& Sutton 2004:152). Bajpai (2010:267) explains snowball sampling as the selection of respondents on the basis of referrals from other respondents, rather as a rolling snowball collects ice particles. These methods are used when it is not possible to obtain access to all the persons in the population or because of time constraints (Cooper \& Schindler 2011:369). One hundred and fifty questionnaires were distributed to respondents in the Nelson Mandela Metropolitan area, of which 120 were deemed useable for this study. The sample size of 120 was deemed sufficient for the study based on the exploratory nature of the research, as well as the 20:1 rule, which states that the ratio of the sample size to the number of parameters under investigation should be at least 20 to 1 (Burmeister \& Aitken 2012:271274). The effective response rate for this study was $80 \%$, which conforms to Babbie and Mouton's (2011:261) guideline for a good response rate. Given this high response rate, non-response bias was not regarded as a problem in this study. 


\section{Empirical results}

\subsection{Description of the sample}

There was an almost even split between female (52\%) and male $(48 \%)$ respondents in this study. The majority of the respondents were managers $(61 \%)$, while 16 percent were owners and 4 percent were CEOs. The remaining respondents (19\%) were either normal employees or consultants. The majority (38\%) of the respondents had been employed for a period of one to five years by the businesses that participated in the study; 24 percent had been employed for six to ten years; 21 percent for more than 15 years; and 17 percent for 11 to 15 years.

In respect of the demographics, 63 percent were small businesses (employing fewer than 50 employees), followed by large businesses (23\%) and medium businesses (14\%) which employ between 51 and 200 employees. The majority $(70 \%)$ of the respondents conduct their business in the private sector. The public sector represented only 30 percent of the respondents. This study analysed businesses from various industries: 42 percent of the respondents worked within the retail and wholesaling industries, and 14 percent in the financial, insurance, and real estate industries, while 17 percent were from a variety of 'other' industries such as consulting firms, laundromats, electricity, and hospitality. Respondents from the manufacturing industry made up only 7 percent of the sample.

Most of the businesses were private companies (39\%) while 28 percent were close corporations. These two forms of ownership accounted for the largest proportion of respondents. The rest were from sole traders $(8 \%)$, partnerships $(14 \%)$, public companies $(8 \%)$, and trusts $(3 \%)$. In relation to the business' involvement in sustainability reporting, the majority $(51 \%)$ had been involved in sustainability reporting for five years or more. Of the respondents, 23 percent had been involved in sustainability reporting for less than one year, while 13 percent had been involved for one to two years, and another 16 had been involved for three to four years.

\subsection{Results of the validity and reliability analysis}

In order to determine the validity of the measuring instrument, the researchers used the exploratory factor analysis to find out which variables were correlated with each other and which variables were independent of each other. For the purposes of this study, items with a factor loading of 0.5 or greater were accepted and considered significant. In order to determine the reliability of the measuring instrument, the researchers used Cronbach's alpha coefficient to test the inter-relatedness of the items in the construct. For the purpose of this study, Cronbach's alpha coefficients of 0.7 (Lehman, 2005:145; Nunnnally \& Bernstein, 1994) indicated that a scale was reliable. Table 1 summarises the details of the validity and reliability of the measuring instrument. From Table 1 it can been seen that the scales measuring the aspects of triple bottom line reporting showed evidence of acceptable validity and reliability.

\begin{tabular}{|l|l|l|l|}
\hline Variables & \multirow{2}{*}{ Items } & $\begin{array}{l}\text { Factor } \\
\text { loadings }\end{array}$ & Cronbach's Alphas \\
\cline { 1 - 3 } 'Benefits of triple bottom line reporting & 7 & $\begin{array}{l}\text { Max: } 0.733 \\
\text { Min: } 0.514\end{array}$ & 0.9114 \\
\hline 'Benefits of financial reporting' & \multirow{2}{*}{6} & $\begin{array}{l}\text { Max: } 0.767 \\
\text { Min: } 0.550\end{array}$ & 0.8637 \\
\cline { 1 - 1 } 'Benefits of social reporting' & \multirow{2}{*}{8} & $\begin{array}{l}\text { Max: } 0.677 \\
\text { Min: } 0.518\end{array}$ & 0.8495 \\
\hline 'Benefits of environmental reporting' & 7 & $\begin{array}{l}\text { Max: } 0.683 \\
\text { Min: } 0.518\end{array}$ & 0.8806 \\
\hline
\end{tabular}

Table 1: Validity and reliability results

Source: Calculated from survey results EFA analysis

\subsection{Operationalisation of factors}

Following the validity and reliability results, the variables under investigation in this study were operationalised as follows:

'Benefits of triple bottom line reporting' refers to providing a significant focus on the measurement of intangible assets and the reputation of the business; triple bottom line reporting providing relevant and 
useful business information; triple bottom line reporting being used to determine the financial, social, and environmental status of the business;

'Benefits of financial reporting' refers to the financial aspect of triple bottom line reporting revealing the real financial status of the business; triple bottom line reporting being a financially viable business practice; long-term financial planning being influenced by triple bottom line reporting;

'Benefits of social reporting' refers to social responsibility reporting leading to higher quality relationships between employees and the business; social reporting increasing communication between the business and its stakeholders; contact sessions with local communities promote information and idea exchanges;

'Benefits of environmental reporting' refers to environmental measures that are used, including management of electricity consumption and solid waste, and integrated pest management; keeping stakeholders are better informed about green production processes as reflected in the sustainability report;

\subsection{Analysis of variance (ANOVA)}

An analysis of variance (ANOVA) was performed to determine whether there were any significant differences between the means of the demographic variables when tested against the four factors of triple bottom line reporting. An ANOVA is a statistical method for making comparisons between two or more means, to determine whether significant relationships exist between the variables (Thomas, Nelson \& Silverman, 2010:168). This was done by analysing the ANOVA output to observe whether there were statistically significant differences between the group means. In conducting the ANOVA test, the demographic variables of the businesses were the independent variables, namely Size of the business, Industry, Sector of the business, Form of ownership, Management style, and Length of involvement in triple bottom line reporting.

Table 2 shows the results of the ANOVA between the demographic variables (Size of the business, Industry, Sector of the business, Form of ownership, Management style, and Length of involvement in triple bottom line reporting) and the Benefits of triple bottom line reporting. The results of the ANOVA show that a significant relationship did emerge between the demographic variable Industry $(\mathrm{p}<0.05)$ and Management style $(\mathrm{p}<0.05)$. The mean score reported for the Benefits of triple bottom line reporting was higher in large businesses $(\bar{x}=3.841)$ than in small businesses $(\bar{x}=3.063)$. Furthermore, Benefits of triple bottom line reporting was higher for businesses in the leisure and entertainment industry $(\bar{x}=4.200)$ than for all the other industries. Benefits of triple bottom line reporting also showed a higher mean score in those who believed that management style influences triple bottom line reporting and increases managerial credibility $(\bar{x}=3.775)$, compared with the respondents who did not believe this to be the case $(\bar{x}=2.600)$.

\begin{tabular}{|l|l|l|}
\hline Demographic variables: & F-value & Sig. $(\mathrm{p})$ \\
\hline Size of the business & 0.826 & 0.0641 \\
\hline Industry & 4.857 & $0.0283^{*}$ \\
\hline Form of ownership & 0.910 & 0.3407 \\
\hline Management style & 1.865 & $0.0171^{*}$ \\
\hline Length of time of involvement in triple bottom line reporting & 2.505 & 0.0834 \\
\hline (Bold $^{*}=$ p-value $\left.<0.05\right)$ & \multicolumn{2}{|l}{} \\
\hline
\end{tabular}

Table 2: Demographic variables and benefits of triple bottom line

Source: Calculated from survey results ANOVA analysis

Table 3 shows the results of the ANOVA between the demographic variables and the Benefits of financial reporting. The results of the ANOVA show that a significant relationship did emerge between the demographic variable Size of the business $(p<0.05)$ and Benefits of financial reporting. The mean score reported for Benefits of financial reporting was higher in medium sized businesses $(\bar{x}=3.911)$ than in small businesses $(\bar{x}=3.71)$ and large businesses $(\bar{x}=3.791)$. The other demographic variables did not exert a significant influence on the Benefits of financial reporting. 


\begin{tabular}{|l|l|l|}
\hline Demographic variables: & F-value & Sig. $(\mathrm{p})$ \\
\hline Size of the business & 1.219 & 0.0175 \\
\hline Industry & 0.500 & 0.4800 \\
\hline Form of ownership & 0.225 & 0.6359 \\
\hline Management style & 4.108 & 0.4436 \\
\hline Length of time of involvement in triple bottom line reporting & 0.565 & 0.5687 \\
\hline (Bold = p-value $<0.05$ ) & \multicolumn{2}{|l}{} \\
\hline
\end{tabular}

Table 3: Demographic variables and benefits of financial reporting

Source: Calculated from survey results ANOVA analysis

Table 4 shows the results of the ANOVA between the demographic variables and the Benefits of social reporting. The results of the ANOVA show that a significant relationship did emerge between the demographic variable Industry $(\mathrm{p}<0.05)$ and Benefits of social reporting. The mean score reported for Benefits of social reporting was higher for businesses operating in the communication $(\bar{x}=3.930)$ and financial, insurance, and real estate $(\bar{x}=3.720)$ industries than in the other industries. The other demographic variables did not exert a significant influence on Benefits of social reporting.

\begin{tabular}{|l|l|l|}
\hline Demographic variables & F-value & Sig. $(\mathrm{p})$ \\
\hline Size of the business & 2.253 & 0.1344 \\
\hline Industry & 3.262 & 0.0018 \\
\hline Form of ownership & 0.034 & 0.4330 \\
\hline Management style & 2.306 & 0.2990 \\
\hline Length of time of involvement in triple bottom line reporting & 1.098 & 0.3348 \\
\hline (Bold = p-value<0.01) & \multicolumn{2}{|l}{} \\
\hline
\end{tabular}

Table 4: Demographic variables and Benefits of social reporting

Source: Calculated from survey results ANOVA analysis

Table 5 shows the results of the ANOVA between the demographic variables and the Benefits of environmental reporting. The results of the ANOVA show that a significant relationship did emerge between the demographic variable Size of the business $(p<0.05)$ and Benefits of environmental reporting. The mean score reported for the dimension Benefits of Environmental reporting was higher in large businesses $(\bar{x}=3.790)$ than in small or medium sized businesses $(\bar{x}=3.340)$. The other demographic variables did not exert a significant influence on the Benefits of environmental reporting.

\begin{tabular}{|l|l|l|}
\hline Demographic variables & F-value & Sig. $(\mathrm{p})$ \\
\hline Size of the business & 0.1154 & 0.0049 \\
\hline Industry & 0.0766 & 0.7821 \\
\hline Form of ownership & 0.8871 & 0.3470 \\
\hline Management style & 0.0000 & 1.0000 \\
\hline Length of time of involvement in triple bottom line reporting & 2.0943 & 0.7343 \\
\hline (Bold = p-value<0.01) & \multicolumn{2}{|l}{} \\
\hline
\end{tabular}

Table 5: Demographic variables and Benefits of environmental reporting

Source: Calculated from survey results ANOVA analysis

\section{Discussion of significant findings}

The findings highlight that there was a relationship between the kind of industry and the benefits of triple bottom line reporting. Thus, $\mathrm{H}^{1 \mathrm{a}}$ is accepted. It was found that the leisure and entertainment industry $(\bar{x}=4.200)$ agreed that triple bottom line reporting allows for a focus on the measurement of intangible assets and the reputation of the business. This industry also perceived that triple bottom line reporting provides relevant and useful business information, and is useful in determining the financial, social, and environmental status of the business. It was also believed that a focus on the social and environmental aspects of triple bottom line reporting would enhance the business' standing as a good corporate citizen and increase its operational and economic efficiency. The benefits of triple bottom line reporting were perceived as leading to better transparency and accountability for the specific industry. 
Additionally, management style was a significant factor in the perceived benefits of triple bottom line, which was similar to the findings of other authors (Ng and Burke 2010:610; Fifka \& Meyer 2013:6).

The findings also indicated a relationship between the size of the business and the benefits of financial reporting. Thus $\mathrm{H}^{1 \mathrm{~b}}$ is accepted. This means that large businesses saw it as more beneficial to produce a financial report than did small or medium businesses. Large businesses $(\bar{x}=3.911)$ also believed that reporting their data in a financial manner revealed the business' financial status. They also saw triple bottom line reporting as a financially viable business practice. They considered financial reporting to be the most important part of triple bottom line reporting, and that it led to efficient and streamlined business practices that could save them money. Additionally, ethical financial reporting was viewed as strengthening trust between the business and its stakeholders, thus improving their credibility. This finding concurs with the findings of Ekwueme, Egbunike and Onyali (2013:79-91) who state that the ethical financial reporting is important for safeguarding businesses against potential legal hassles and building stakeholder trust.

A relationship was also present between the type of industry and the perceived benefits of social reporting. Thus, $\mathrm{H}^{1 \mathrm{c}}$ is accepted. The businesses operating in the communication industry $(\bar{x}=3.930)$ and financial, insurance, and real estate industry $(\bar{x}=3.720)$ agreed that socially responsible reporting led to a high quality of relationship between employees and a business. This finding was also noted by Ekwueme et al. (2013:79-91) who found that implementing triple bottom line principles improved employee motivation and reduced labour turnover. They also saw this type of reporting increasing communication between a business and its stakeholders. These industries also believed that their corporate social responsibility performance could be compared with international and local benchmarks. They perceived the benefits of social reporting as a way of making contact with local communities to promote information and the exchanges of ideas. They viewed sponsorships and donations towards social development as part of triple bottom line reporting. They also believed that the development of skills and talent in underdeveloped communities should be prioritised as a social responsibility activity. Another benefit of reporting on the social aspects was the belief that social responsibility helped them to comply with relevant laws and regulations that have strategic importance for the business.

Lastly, a relationship was also found between the size of the business and the benefits of environmental reporting. Thus, $\mathrm{H}^{1 \mathrm{~d}}$ is accepted. Large business $(\bar{x}=3.790)$ agreed that the effects of pollution and wastage should be revealed in their environmental report. They also saw recycling and reusing wastage and conserving of energy and water led to environmental benefits and cost savings for the business. They also believed that the intrinsic value of reusable and recycling material should be revealed in the sustainability reports, and that businesses should have an eco-efficient purchasing policy. Furthermore, they agreed that stakeholders are better informed about green production processes that are reflected in the sustainability report.

\section{Implications of significant findings}

From the findings it is evident that large businesses find it more beneficial to report on the financial and environmental aspects of sustainability. This means that large businesses do not believe in the value of engaging in social corporate responsibility and reporting on these activities. Van Zyl (2013:920) highlights that many businesses give little attention to social sustainability reporting, especially environmental justice, as many of them find it difficult to contextualise their impact, and thus make no disclosures. This may suggest that stakeholders need to exert pressure on large businesses to ensure that they communicate more frequently with them. This supported by Stubbs et al. (2013:467), who urge stakeholders to exert more pressure and to indicate the type of information they want the business to include in meaningful disclosures. This can be achieved by businesses making contact with local communities in order to provide information and to exchange ideas. This will help them to understand the local community's views before any social investment takes place. Large businesses should also seek the employees' views on local social investments, especially about sponsorships and donations to local community development. This approach will lead to employees' views being considered before any social investments are made, and thus help to achieve high quality relationships between the business and its employees. 
Certain industries seem to see more value in reporting on the social aspects of the triple bottom line than do others. Sotorrío and Sánchez (2010:282) found significant differences in social reporting for different audiences. For example, they found that social reporting is higher for worldwide stakeholders than for local ones, and that it is associated with company size and the reputation of the business (Sotorrío \& Sánchez 2010:282). Industry effect was also present in the benefits of triple bottom line reporting. This means that businesses in the communication, finance, insurance, and real estate industries see the benefits of the social aspects but not of the financial and environmental aspects of triple bottom line reporting. As part of triple bottom line reporting, financial reporting must reveal the financial status of the business through the income and expenditure and balance sheet statements. These financial statements must be an indicator of the financial status of the business, and the benefits and costs of triple bottom line reporting must be made explicit. This means that both the costs and the savings of implementing sustainability activity must be highlighted. This will make it possible for businesses to decide whether it is financial viable to practice triple bottom line reporting. Certain industries also need to be conscious of the benefits of using environmental measures such as the management of electricity consumption and solid waste. This includes having measures in place to disclose information about green production processes used by businesses, thus keeping stakeholders informed. Lastly, businesses must contextualise their reporting so that the impact of recycling and of the conservation of energy and water is indicated in terms of cost savings.

\section{Limitations and recommendations for future research}

Despite the best intentions of this study, the following limitations are noted. The findings of this study identify areas that require further explanation. For example, it is known that the type of industry and the size of business are significant to the benefits of triple bottom line reporting. However, no explanation is given for this trend, and thus future studies could consider employing qualitative studies to understand why small and large business may have different perceptions of the benefits of triple bottom line reporting. Lastly, other demographic factors might influence businesses' perception of triple bottom line reporting. Thus, future studies should think about extending the demographic factors used in this study.

\section{Concluding remarks}

Triple bottom line reporting provides useful and relevant business information. Triple bottom line reports not only benefit the community but the economic stability of the business as consumers are more likely to support organisations that give back or that are transparent and accountably. This study added to the body of knowledge on triple bottom line reporting by businesses in developing nations. The empirical results showed that some demographic variables, namely - the size of the business, the industry in which the business operates, and the management style of the business - had a significant influence on the business's triple bottom line reporting. As noted in the limitations and recommendations for future research, there is still more to be done in order to understand the different perceptions of the benefits of triple bottom line reporting.

\section{References}

Babbie, E.R. (2010). The practice of social research. 12 $2^{\text {th }}$ edition. Belton CA: Wadsworth Cengage Learning.

Babbie, E. \& Mouton, J. (2001). The practice of social research, Oxford University Press, Cape Town.

Bajpai, N. (2010). Business Statistics. India: Dorling Kindersley.

Blowfield, M. \& Murray, A. (2008). Corporate responsibility: A critical introduction. New York: Oxford University Press.

Bosch, J.K., Tait, M. \& Venter, E. (2018). Business management: An entrepreneurial perspective. $3^{\text {rd }}$ edition. Port Elizabeth: Lectern.

Burmeister, E. \& Aitken, L.M. (2012). Sample size: How many is enough? Australian Critical Care, Vol. 25, No. 4, pp.271-274.

Chapman, R. \& Milne, J.M. (2003). The triple bottom line: How New Zealand companies measure up. New Zealand: University of Otago.

Collins, E., Roper, J. \& Lawrence. (2010). Sustainability practices: Trends in New Zealand businesses. Business Strategy and the Environment, Vol. 19, No. 8, pp.479-494.

Cooper, D.R. \& Schindler, P.S. (2008). Business research methods. 10 th edition. New York. 
Correia, C., Flynn, D., Uliana, E., Wormald, M. \& Dillon, J. (2015). Financial management. $8^{\text {th }}$ edition. Cape Town: Juta.

David, M. \& Sutton, C.D. (2004). Social research: The basics. London: SAGE Publications.

Dutta, S. (2012). Triple bottom line reporting: An Indian perspective. Interdisciplinary Journal of Contemporary Research in Business, Vol. 3, No. 12, pp.652-659.

Ekwueme, C. M. Egbunike, C. F. \& Onyali, C. I. (2013). Benefits of triple bottom line disclosures on corporate performance: An exploratory study of corporate stakeholders. Journal of Management and Sustainability, Vol. 3, No. 2, pp.79-91.

Fifka, M.S., \& Meyer, J. (2013). Corporate responsibility reporting and its determinants in comparative perspective: A review of empirical literature and a meta-analysis. Business Strategy and the Environment, Vol. 22, No. 1, pp.1-35.

Gimenez, C., Seirra, V. \& Rodon, J. (2012). Sustainable operations: Their impact on the triple bottom line. International Journal Production Economics, Vol. 140, No. 1, pp.149-159.

Goel, P. (2010). Triple bottom line: An analytical approach for corporate sustainability. Journal of Finance, Accounting and Management, Vol. 1, No. 1, pp.27-42.

Gomes, C. M., Kneipp, J.M., Kruglianskas Rosa, L.A.B. \& Bichueti, R.S. (2015). Management for sustainability: An analysis of key practices according to the business size. Ecological Indicators, Vol. 52, No. 1, pp.116-125.

Gray, R. \& Milne, M.J. (2002). Sustainability reporting: Who's kidding whom? New Zealand: University of Otago.

Hellriegel, D., Slocum, J., Jackson, S.E., Louw, L., Staude, G., Amos, T., Klopper, H.B., Louw, M., Oosthuizein, T., Perks, S. \& Zinyide, S. (2012). Management. $4^{\text {th }}$ edition. Cape Town: Oxford University Press.

Hindle, T. (2009). Triple bottom line. [Online] Available: http://www.economist.com/node/14301663 [Accessed 12 April 2013].

Ho, L.J. \& Taylor, M.E. (2007). An empirical analysis of triple bottom-line reporting and its determinants: Evidence from the United States and Japan. Journal of International Financial Management and Accounting, Vol. 8, No. 2, pp.123-150.

Jackson, A., Boswell, K. \& Davis, D. (2011). Sustainability and triple bottom line reporting - What is it all about? International Journal of Business, Humanities and Technology, Vol. 1, No. 3, pp.55-59.

Jamali, D. (2006). Insights into triple bottom line integration from a learning organisation perspective. Business Process Management Journal, Vol. 12, No. 6, pp.809-821.

Keller, G. \& Warrack, B. (2003). Statistics for management and economics. $6^{\text {th }}$ edition. California: Thomson-Brooks/Cole.

Lehman, A. (2005). JMP for basic univariate and multivariate statistics: A step-by-step guide. London: SAGE Publications.

Millar, H. \& Russell, S. (2011). The adoption of sustainable manufacturing practices in the Caribbean. Business Strategy and the Environment, Vol. 20, No. 8, pp.512-526.

Milne, J.M., Tregidga, H. \& Walton, S. (2003). The triple-bottom-line: Benchmarking New Zealand's early reporters. New Zealand: University of Otago.

Naudé, J.A. (2008). A framework for reporting sustainability performance to major stakeholders group. Doctoral thesis. Pretoria: University of South Africa.

Nemli, E. (2004). The status of corporate sustainability in Turkish companies. [Online] Available:

http://opim.wharton.upenn.edu/gc/philadelphia/abstract/ Nemli.pdf [Accessed 30 March 2013].

Ng, E.S. \& Burke, R.J. (2010). Predictor of business students' attitudes towards sustainability business practices. Springer, Vol. 95, No. 4, pp.603-615.

Norman, W. \& MacDonald, C. (2004). Getting to the bottom of “triple bottom line". Business Ethics Quarterly, Vol. 14, No. 2, pp.243-262.

Nunnally, J.C. \& Bernstein, I.H. (1994). Psychometric theory. $3^{\text {rd }}$ edition. New York: McGraw.

Orlitzky, M. (2000). Corporate social performance: Developing effective strategies. Sydney: Centre for Corporate Change.

Reddy, R. (2007). Guidelines to evaluate social performance. Microfinance Gateway.Washington: Accion Publishers.

Rogers, M. (2001). The triple bottom line for sustainable community development. Local Environment, Vol. 6, No. 3, pp.279-289.

Savitz, A.W. \& Weber, K. (2006). The triple bottom lines. [Online] Available: http://www.amazon.com/The-TripleBottom-Line-Environmental/product-reviews/0787979074. [Accessed 12 April 2013].

Simerly, R.L. (2003). An empirical examination of the relationship between management and corporate social performance. International Journal of Management, Vol. 18, No. 2, pp.148-155.

Slaper, T.F. \& Hall, T.J. (2011). The triple bottom line: What it is and how it works? Indiana Business Review, Vol. 86, No. 1, pp.4-8.

Sotorrío, L.L. \& Sánchez, J.F. (2010). Corporate social reporting for different audiences: The case of multinational corporations in Spain. Corporate Social Responsibility and Environmental Management, Vol. 17, No. 5, pp.272-283.

Sridhar, K. (2011). A multi-dimensional criticism of the triple bottom line reporting approach. International Journal of Business Governance and Ethics, Vol. 6, No. 1, pp.49-67.

Sustainability Reporting Program. (2000). A brief history of sustainable development. Available:

http:/ / www.sustreport.org [Accessed 31 March 2011]. 
Swallow, L. (2009). Green business practices for dummies. New Jersey: Wiley.

The Business Leaders. (2009). Draft code of governance principles for South Africa - 2009: King Committee on Governance. South Africa: Institute of Directors in Southern Africa.

The New Zealand Ministry of Education. (2012). Aspects of sustainability. New Zealand curriculum guides: Senior Secondary. [Online]. Available:

http:/ / seniorsecondary.tki.org.nz/Social-sciences/Education-for-sustainability/Key-concepts/Aspects-ofsustainability [Accessed 5 April 2013].

Thomas, J., Nelson, J.K. \& Silverman, S. (2010). Research methods in physical activity. $6^{\text {th }}$ edition. New York: Thompson Shore.

Wilson, M. (2003). Corporate sustainability: What is it and where does it come from? Ivey Business Journal, Vol. 67, No. 1, pp.1-5.

Yilmaz, A.K. \& Flouris, T. (2010). Managing corporate sustainability: Risk management process based perspective. African Journal of Business Management, Vol. 4, No. 2, pp.162-171. 